удк 332.132

\title{
ВПЛИВ ГАЛУЗЕВО-РЕГІОНАЛЬНОГО АСПЕКТУ НА ПРОСТОРОВЕ ОРГАНІЗУВАННЯ ПІДПРИЄМНИЦЬКОЇ ДІЯЛЬНОСТІ
}

\section{INFLUENCE OF INDUSTRIAL-REGIONAL ASPECT ON SPATIAL ORGANIZATION OF ENTREPRENEURSHIP ACTIVITY}

\author{
Василюк Софія Володимирівна \\ кандидат хімічних наук, старший науковий співробітник, \\ Національний університет «Львівська політехніка» \\ ORCID: https://orcid.org/0000-0003-2946-0513 \\ Vasulyuk Sofiya \\ Lviv National Polytechnic University
}

\begin{abstract}
Визначено, що важливим питанням сьогодення є економічне районування. Обґрунтовано, що вирішення цілої низки економічних задач тією чи іншою мірою пов'язане з економічним районуванням. Визначені характерні риси економічних територій. Доведено, що при визначенні економічного району правильний підхід буде тоді коли економічні території як такі, а також території ринків праці, вважатимуть своїм центром місто. Визначено, що сильні міста заохочують природній розвиток чинників субурбанізації, а слабші центральні міста мають на неї негативний вплив зі зростанням частки мешканців, що переселяються за межі центрального міста. Доведено, що територіально-галузевий аспект оцінки господарської діяльності дає змогу оптимізувати розміщення галузей національної економіки, яка базується на аналізі потреб країни загалом й окремих регіонів у певних видах продукції, наявності виробничих можливостей, трудових, енергетичних, паливних, сировинних ресурсів.

Ключові слова: просторове орієнтування бізнесу, галузево-регіональний аспект в процедурі розміщення підприємств, регіональне оточення бізнесу, регіональна економіка, розвиток продуктивних сил, метрополіс.
\end{abstract}

Определено, что важным вопросом сегодня является экономическое районирование. Обосновано, что решение целого ряда экономических задач в той или иной мере связано с экономическим районированием. Определены характерные черты экономических территорий. Доказано, что при определении экономического района правильный подход будет тогда, когда экономические территории как таковые, а также территории рынков труда, будут считать своим центром город. Определено, что сильные города поощряют естественное развитие фракторов субурбанизации, а более слабые центральные города имеют на нее негативное влияние с ростом доли жителей, переселяемых за пределы центрального города. Доказано, что территориальноотраслевой аспект оценки хозяйственной деятельности позволяет оптимизировать размещение отраслей национальной экономики, которая базируется на анализе потребностей страны в целом и отдельных регионов в определенных видах продукции, наличии производственных возможностей, трудовых, энергетических, топливных, сырьевых ресурсов.

Ключевые слова: пространственное ориентирование бизнеса, отраслево-региональный аспект в процедуре размещения предприятий, региональное окружение бизнеса, региональная экономика, развитие производительных сил, метрополис.

It is determined that economic zoning is an important issue today. It is the basis for the formation of state regional economic policy and has enormous practical value in the territorial management of the economy. It is proved that to solve a number of economic problems, including the development of territorial production complexes, improving the territorial structure of the economy, the choice of rational location of new industries, etc., to some extent associated with economic zoning. The process of general economic zoning of the territory, which promotes the creation of effective territorial schemes of spatial orientation and development of productive forces, which is implemented in Ukraine in order to develop and implement comprehensive programs of environmental management and resettlement. It is proved that the concept of economic zoning is transformed into a rather scientifically substantiated method of spatial organization of the national economy. Skillful implementation of this method is an acceptable and effective means 
of promoting socio-economic development and rational spatial organization of industrial complexes. The concept of "economic territory" as a functional key unit, which consists of all economic components of the territory, is substantiated. The characteristic features of economic territories are determined. It is proved that the correct approach in determining the economic area will be when the economic territories as such, as well as the territories of labor markets, will consider the city as their center. The statement that the city itself is a driving force in the process of economic growth is substantiated. Significant dependence of suburbs on cities in the economic space is proved. It is determined that strong cities encourage the natural development of suburbanization factors, and weaker central cities have a negative impact on it with the growing share of residents moving outside the central city. It is substantiated that the reputation and viability of the metropolitan area form the economic result of the central city. If the central city is allowed to decline, it will negatively affect the entire metropolitan area. Businesses refuse to relocate, invest or simply stay in areas where the central city is characterized by high crime rates, low levels of education, inadequate services, and so on. It is proved that the territorial-sectoral aspect of economic activity assessment allows to optimize the location of sectors of the national economy, which is based on the analysis of the needs of the country as a whole and individual regions in certain products, production capacity, labor, energy, fuel and raw materials.

Keywords: spatial orientation of business, branch-regional aspect in the procedure of enterprise placement, regional business environment, regional economy, development of productive forces, metropolis.

Постановка проблеми. Безумовно важливим питанням сьогодення $є$ економічне районування. Воно $є$ підґрунтям для формування державної регіональної економічної політики та має колосальне прикладне значення в територіальному управлінні господарством. Вирішення цілої низки економічних задач, серед яких, розвиток територіально-виробничих комплексів, вдосконалення територіальної структури господарства, вибір раціонального місця розміщення нових виробництв і т.п., тією чи іншою мірою пов'язане з економічним районуванням.

Аналіз останніх досліджень і публікацій. В Україні з метою розроблення та реалізації комплексних програм раціонального природокористування та розселення населення впроваджено генеральне економічне районування території, яке сприяє створенню ефективних територіальних схем розміщення та розвитку продуктивних сил. Процес розроблення ефрективної схеми розміщення та розвитку продуктивних сил окремо вибраного району $€$ доволі клопіткою науково-дослідною роботою прикладного характеру, виконання якої передбачає проведення ретроспективного аналізу розвитку усіх компонентів господарського комплексу і прогнозування напрямів їх ефрективної розбудови та удосконалення. При цьому обґрунтовуються основні завдання і показники соціально-економічного розвитку регіонів та шляхи вирішення соціальних, економічних і екологічних проблем [3; 4].

Беручи до уваги викладене вище, концепція економічного районування трансфрормується в доволі науково обґрунтований метод територіальної організації національного господарства. Вправна реалізація цього методу $є$ прийнятним та ефективним засобом сприяння соціально-економічному розвитку і раціональному розташуванню виробничих комплексів.
В 1980 p. W. Zelinsky запропонував цікаву концепцію «загальновідомих регіонів», в якій як загальновідомий регіон розглядалося «спонтанне бачення територіальної реальності, яке поділяють усі» [19]. W. Zelinsky виокремив загальновідомі регіони, які, як він стверджує, є важливими для розуміння основних проблем нашого суспільства. Пізніше J. Garreau стверджував, що Північна Америка насправді складається 3 дев'яти держав. Кожна з них, як зазначає J. Garreau, має свою столицю й чітку структуру влади та впливу 3 «національними» кордонами, які не завжди збігаються 3 реальними політичними кордонами [9]. Наше не бачення щодо роздвою сили й незалежності цих регіонів, згідно 3 твердженням J. Garreau, $€$ причиною багатьох невдач публічної політики.

Періодично лунали заклики, деякі з них і ще у 1880-х роках, реструктуризувати географрію Сполучених штатів, щоби краще відобразити соціальну та економічну дійсність національної геограсрії [6; 15]. На початку 1970-x R.G. Tugwell запропонував значну реструктуризацію фредеральної системи. Згідно з його задумом, Сполучені Штати мали перетворитися на фредерацію, яка складалась би з 12 чи більше регіонів [17].

Виникнення міських регіонів визнавалось у пропозиціях із реструктуризації фредеральної системи, яка «різко суперечить демографрічній, економічній та соціальній дійсності сучасного американського життя» [8, с. 39-40]. Створення території муніципалітету міста Торонто в Канаді (средерації місцевих урядів) $\epsilon$ прикладом інституційних змін, що відображали міський регіон. Радикальною пропозицією 1970 року було перевести міські території з населенням понад мільйон осіб у категорію штату [7]. 
Кожна з цих пропозицій відображає розуміння того, що функціональна територія впливу соціальної та економічної організації значно перевищує території політичного контролю політичної влади. Остання пропозиція щодо консолідації міських регіонів відтворює концепцію всебічного міського регіону як фрункціональної субнаціональної економічної одиниці.

Формулювання цілей статті (постановка завдання). Дослідити вплив галузеворегіонального аспекту на просторове організування підприємницької діяльності.

Виклад основного матеріалу дослідження. Географрічне відображення держав, яке найповніше відповідає ідеї економічних регіонів, зосереджених навколо міста - це класифрікація економічних територій. Таким чином визначається поняття «економічна територія» як фоункціональна ключова одиниця, яка складається 3 усіх економічних компонентів території. Кожна територія містить один або більше міських центрів та прилеглих територій, економічна активність яких зосереджена в містах; кожна територія також містить гетерогенні промислові групи. Таке визначення економічної території об'єднує місце роботи і місце проживання робочої сили цієї території, щоб мінімізувати ефект доїжджання до місця роботи 3-поза меж території. До того ж, економічні території мають водночас місцеву та орієнтовану на експорт промисловості.

Можна відзначити такі характерні риси економічних територій: Визначені економічні території охоплюють усю географрію держави. Економічні території відповідають головним критеріям міських економічних територій, тобто це метрополії з містом у центрі та околицями, орієнтованими на домінантний міський центр.

Ці фрункціональні економічні території не відповідають владним повноваженням жодних місцевих органів управління, вони також не завжди відповідають кордонам областей.

Не існує причини, чому економічні регіони повинні збігатися 3 політичними та економічними кордонами держави. За відсутності національної владної (урядової) території ймовірно, що срункціональна економічна територія вийде за межі цих штучних бар'єрів. Втім, не можна заперечувати, що національні кордони та політично нав'язані обмеження ефективно та фрункціонально зменшують, а в деяких випадках розривають економічні зв'язки всередині та між міськими економіч- ними регіонами - наприклад, фррагментація Берлінського економічного регіону перед об'єднанням Західної та Східної Німеччини.

Доцільно відзначити інший, проте близькоспоріднений можливий регіональний поділ який визначає території ринку праці (ТРП). Кожна ТРП складається 3 центрального міста і територій, які прилягають до нього та економічно інтегровані в це місто. Загалом, робітники можуть змінювати місце праці без переселення. ТРП слід визначати у категоріях районів; переважно більші ТРП та міські статистичні території (МСТ) мають ті самі кордони. Невеликі ТРП складаються 3 районів або групи районів із центральною громадою 3 населенням 5000 або більше осіб, у межах яких працівники доїжджають до місця роботи. Земельні території кожної області поділяються на ТРП; тому вони прилягають одна до одної і звичайно не виходять за її межі.

Доступність даних - складна і часто головна проблема у спробі визначити економічні регіони. Здебільшого дані доступні лише тих регіонів, які мають політичні кордони. Більшість субнаціональних і районних територій була визначена державою в межах, які переважно не мають стосунку до економічних структур.

Проте помилок вдається уникнути, якщо економічні території як такі, а також території ринків праці, вважатимуть своїм центром місто. Це - відображення того, що населення та економічна активність у державі централізуються на міських територіях, що передбачає міцний зв'язок між економічним зростанням та урбанізацією.

Економічна активність зосереджена на міських територіях і ще більше, ніж населення. Між 1995 та 2015 рр. на міських територіях спостерігалося вищі темпи приросту населення та працевлаштування, проте зростання кількості робочих місць було майже втричі більшим, ніж зростання населення. Водночас, приблизно 80\% загального зростання працевлаштування відбувалось на міських територіях [2]. Додаткових 12\% були в урбанізованих прилеглих територіях і ще 5\% в урбанізованих неприлеглих територіях. Менше 3\% від загального збільшення кількості робочих місць маємо в повністю сільських округах.

Подальша централізація економічної активності на урбанізованих територіях дає змогу зробити висновок, що економічне зростання та урбанізація тісно пов'язані. Міські території надають майже всі нові робочі місця, створені в економіці. Вони є домом для понад трьох четвертих населення держави. 
Однак лише демографрічних даних недостатньо для того, щоб показати, що місто $€$ рушійною силою в процесі економічного зростання. Упродовж еволюції економіки економісти здебільшого ігнорували взаємозв'язок між містом та економічним зростанням і продуктивністю. J.R. Harris стверджує, що образ міста в економіці був переважно непомітним, а урбанізацію, в кращому випадку, традиційно розглядали як супутника структурних змін, а не як рушійну силу індустріалізації [11]. Функціям міста в процесі індустріалізації не надавали систематичної уваги аж до п'ятдесятих років, коли новаторські статті Е. Лампарда, Б. Ґозеліца та В. Томпсона зосередились на взаємозв'язку між урбанізацією та економічним зростанням і розвитком [12; 14]. Уперше місто стало важливим об'єктом економічних досліджень.

Значною мірою в літературі зосереджуються дослідження міста, а не метрополісу, який постав як функціональна економічна одиниця лише впродовж останніх чотирьох десятиліть. Однак Е. Лампард, Б. Ґозеліц, В. Томпсон та інші пропонують три основні економічні образи метрополісу, особливо доречні в нашому дослідженні. Перший образ продуктивного метрополісу. В даному випадку перевага за виробничими витратами досягається за рахунок концентрації ресурсів в одному місці та близьких відстаней «виробник-споживач». Інший економічний образ образ виробничого метрополісу, розсадника та інкубатора підприємництва й інновацій. Третій образ - метрополіс контролю, центру прийняття рішень, інформації та комунікацій.

Продуктивний метрополіс - реалізація агломеративної економіки, яка виходить із низки чинників. Серед них - мінімізація коштів, пов'язаних із відстанню, у тому числі транспортування, комунікації та час; загальні чинники такі, як об'єднаний фонд кваліфікованої і неквалісрікованої робочої сили та постачальників загальних матеріально-технічних ресурсів; доповнювані стадії виробництва; координація спеціалізованої діяльності, що стає можливою через близькість; доступність соціального капіталу.

Крім того, продуктивний метрополіс $€$ своєрідним джерелом живлення для підприємництва та інновацій, що безумовно відобразиться у підсиленні загальному розвитку. Теза Д. Джейкобс про міста як джерела енергії в національній економіці, вперше викладена у праці «Міста і добробут націй» [13, с. 3-31], ґрунтується на ролі міст у сприянні інноваціям, які стимулюють економічне зростання. Водночас, причинний взаємозв'язок між метрополісом та інновацією залишається невловимим. Д. Джейкобс стверджує, що міста є інкубаторами, оскільки вони сприяють взаємодії винахідників та підприємців. Інші наголошують на важливості технічного постачання, яке зменшує капітальні видатки на інновації.

Труднощі у спробах якісно визначити i випробувати ці твердження були значними, однак зусилля щодо цього були непереконливими. Проте спроби, які зосереджувалися переважно на розвиткові невеликих орірм та їхньому поширенню на більшу територію міста, не заперечують важливої ролі метрополісу у сприянні підприємництву та інноваціям.

Контрольна фрункція метрополісу ґрунтується на зосередженні в міській зоні спеціалізованої інфрормації, комунікацій, взаємодії та поліпшеного транспортування. Просторова близькість цих функцій створює спеціалізоване середовище для головних адміністративних установ (громадських і приватних), фрінансових посередників, тих, хто обробляє дані та спеціалізовані бізнесові послуги. Особливо важливим є концентрація в метрополісі штаб-квартир розгалужених компаній, які контролюють більшість робочих місць в економічній системі держави.

3 цього огляду, виникла концепція, що пов'язує в єдину національну систему теорії регіонального розвитку та теорію міських центрів. При цьому, міський регіон можна охарактеризувати як первинний, основоположний центр запровадження змін, підвищення продуктивності та розвитку. Ця концепція узгоджується з сучасними поглядами міської екології про те, що [5]: «Економічне зростання відбувається в матриці міських регіонів, у формі якої організована просторова економіка. Головним у зв'язку між концепціями регіонального зростання та сучасними центрами зростання $€$ те, що саме міста в міській системі, пов'язані механізмами фрільтрації, а не центрально-периферійний важіль у регіональній системі, зв'язаний мультиплікаторами, що ґрунтуються на експорті, сьогодні просторово організовує економіку. Міста $€$ центрами діяльності та інновації, центральними точками транспортної та комунікаційної мереж, місцями кращої доступності, коли фрірми найлегше пожинають плоди ефректу масштабу і коли індустріальні комплекси можуть досягнути економії коштом місце розташування та урбанізації. Вони заохочують спеціалізацію робочої сили, спеціалізацію 
територій на підставі продуктивної діяльності та ефективності у наданні послуг. Сільськогосподарські підприємства $€$ найесрективнішими поблизу міст. Особливо успішне комерційне сільське господарство що оточує великі міста, тоді як периорерія великих міських регіонів характеризується відсталими, не такими прибутковими економічними системами».

Якщо підходити 3 позиції відмінності між міськими регіональними економіками, то Н. Гансен стверджує, що немає такого поняття, як загальнодержавна економіка. Загальнодержавна економіка $€$ радше сукупністю різнорідних регіонів із різними проблемами та можливостями. Це має важливі наслідки для економічної політики.

Національній політиці та програмам, які безумовно розглядаються як однорідна територію або орієнтовані на якусь «узагальнену» ситуацію, таким чином не вдається взяти до уваги те, що нація $є$ сукупністю різнорідних регіонів [10].

Відмінність економічних показників регіонів може не узгоджуватися 3 припущенням про єдину, певною мірою однорідну, національну економіку. Величина відхилень дає змогу припустити, що регіональні економіки можуть бути базовими економічними будівельними блоками.

Майже всі показники економічної активності відображають подібні тенденції коливань серед міських регіональних економік. Відмінності в місцевих циклах ділової активності відображають, мабуть, найпомітніший приклад розбіжностей серед місцевих економік. Тривалість та амплітуда цих циклів показує, що економічна думка повинна враховувати різноманітність міських територій, їхні унікальні особливості й потреби.

У межах націоналістичної економічної парадигми може бути дуже складно приймати регіональні економіки за справжні економіки та базові складові для побудови національної та глобальної економічних систем. Проте різноманітність поведінки цих економічних регіонів із центрами в метрополісах не дозволяє дотримуватися припущення про існування єдиної, певною мірою гомогенної національної економіки.

Сьогодні здебільшого існують явно орієнтовані на центр регіональні економіки, а отже, середньонаціональні показники приховують суттєві розбіжності у діяльності цих регіональних економік. Очевидним $€$ і внутрішній економічний зв'язок та взаємозалежність між цими місцевими економічними регіонами.
Необхідність зв'язку місцевих економічних районів часто губиться у громадських і наукових дискусіях та через зосередження уваги на відносинах (чи їх відсутності) між центральними містами та їх передмістями. Втягнуті в дебати, що використовують як одиниці аналізу сорери державних повноважень, дійові особи та спостерігачі так само повторюють помилку націоналістичної парадигми на місцевому рівні - прирівнюють економічне до державоуправлінського. 3 цього погляду, економіка не має жодних чітких обмежень, окрім обмеження сорери державних повноважень.

Проблема, яку ми тут розглядаємо, часто формулюється у загальних дискусіях щодо того, чи можуть передмістя процвітати і досягати успіху незалежно від достатку й добробуту центрального міста. Тому постає питання, чи фрормується економіка передмістя за допомогою господарства центрального міста і чи залежать передмістя від центральних міст.

Ми вважаємо, що основним є місцевий економічний регіон, для якого адміністративні території міста і передмість $€$ лише складниками. Адміністративні території не є самостійними економіками; це - влада, розташована в межах більшої економічної системи. Цілісність цього економічного регіону спричиняє взаємний зв'язок між станом економіки міста і передмість. Специоріка цієї взаємозалежності для різних метрополісних територій буде відрізнятися. Пояснити це можна тим, що місто і передмістя $€$ елементами більшого економічного цілого.

Інші дослідники розділяють нашу думку стосовно взаємозалежності міст та передмість. Р. Войт в [18] досліджував, чи можна міста і передмістя класифрікувати як доповнювачі та замінники. Він зробив висновок, що «занепад центральних міст спричиняють передмістя, які повільно зростають», і зауважує, що жителі передмість часто не хочуть визнавати це тому, що «передмістя часто фрункціонує набагато краще, ніж його занепадаючий партнер - центральне місто».

Г. Савіч 3 колегами досліджували залежність між доходами, робочими місцями й характеристиками населення для міст та передмість. Ці дослідники встановили взаємозалежність між змінами доходу та бідністю і зробили висновок, що «падіння внутрішнього міста кидає довгу тінь. Компанії не зростатимуть і не просуватимуться в середовищі, що занепадає» [16].

Отже, сильні міста заохочують природній розвиток чинників субурбанізації, а слабші 
центральні міста мають на неї негативний вплив зі зростанням частки мешканців, що переселяються за межі центрального міста.

Відмінності між центральними містами та передмістями мають незначне економічне значення як окремі одиниці приватного виробництва (за винятком визначальної ролі місцевих податків у ділових рішеннях щодо місця розташування та виробничих витрат), фрормування доходів чи нагромадження багатства. Придатними для цих дій економічними одиницями є метрополісні території, бо вони охоплюють ринки праці та земельні ресурси.

Репутацію і життєспроможність метрополісної території фрормують економічний результат діяльності центрального міста. Якщо дозволити центральному місту занепасти, це негативно впливає на всю метрополісну територію. Підприємства відмовляються переміщуватись, інвестувати чи просто залишатись на території, де центральне місто характеризується високим рівнем злочинності, низьким рівнем освіти, невідповідними послугами, тощо.

Розвиваючи тезу, що економічні регіони $€$ основною економічною одиницею та будівельними блоками для більших економічних систем, ми передусім демонструємо радше існування суттєвої різноманітності в діяльності регіонів, аніж однорідність, передбачену націоналістичною парадигмою економіки.

Можемо обґрунтовано стверджувати, що регіони також внутрішньо взаємопов'язані, тобто вони є окремими, внутрішньо взаємозалежними економіками чи економічними регіонами.

Можливо, найсуттєвіший приклад різноманітності місцевих економік можна знайти в дослідженні місцевих циклів ділової активності Тобто, існування місцевих циклів ділової активності демонструє процес внутрішньої інтеграції місцевих економічних регіонів, але, ще важливіше - руйнує образ «національних тенденцій», незалежних від місцевих чинників.

Дослідження процесів розвитку і просторової організації виробничо-господарської діяльності провадиться на основі сумарності багатьох підходів. Серед них доцільними на різних рівнях освоєння є такі: галузевий, міжгалузевий, регіональний, системно-структурний, історичний, комплексний, екологічний, проблемний, програмно-цільовий, відтворювальний [1, с. 37].

Територіально-галузевий аспект на основі аналізу поділу праці дає змогу обґрунтувати спеціалізацію виробництва окремих регіонів переважаючий розвиток виробництва певних видів продукції чи виконання відповідних національно-господарських функцій із урахуванням найесрективнішого використання сприятливих природних й економічних умов району та раціональної участі в територіальному поділі праці.

На основі загального поділу праці 3'ясовують співвідношення сфер виробництва товарів й надання послуг. У виробничій сорері - співвідношення промисловості, сільського господарства, будівництва, транспорту; у сорері послуг - співвідношення освіти, охорони здоров'я, культури та ін. На основі часткового поділу праці визначають співвідношення у промисловості - машинобудуванні, хімічній, легкій та інших галузях; у сільському господарстві - рослинництві, тваринництві тощо. На основі одиничного поділу праці - структуру зайнятості за професіями, рівнем кваліфікації тощо. Територіально-галузевий аспект аналізу розміщення й фрункціонування продуктивних сил передбачає обґрунтування спеціалізації виробництва, обслуговуючої діяльності окремої території області, району, міста, групи областей.

Науковому загалу відомо багато чинників, що можуть впливати на територіальну організацію різних галузей виробництва. При цьому найбільш скрупульозно аналізується вплив транспортного чинника. Подальша трансорормація галузевого підходу полягала у виборі кількох ймовірних точок продукування аналогічних видів продукції з використанням деяких обмежень. Відібрані точки характеризуються відмінними транспортними та виробничими витратами. Варто наголосити і на деяких аспектах недосконалості галузевого підходу. Зокрема, його використання дещо нівелює особливості міжгалузевих зв'язків, які в умовах сьогодення, привертають до себе все більше уваги. Не можна, наприклад, розглядати структуру, спеціалізацію, розвиток і розміщення окремих галузей сільського господарства окремо від розвитку і розміщення певних галузей харчової промисловості. Неповне врахування міжгалузевих зв'язків призводить до помилок і небажаних трансорормаційних процесів у розвитку і розміщенні цих галузей.

Міжгалузевий підхід, або аналіз розвитку і розміщення сукупності галузей, що тісно взаємодіють (за сировинними, проміжними та кінцевими продуктами, технологічними та іншими ознаками), є дещо менш розробленим порівняно з галузевим.

Регіональний підхід ґрунтується на відмінностях людської життєдіяльності характерних 
для того чи іншого регіону та пропагує ідею детального вивчення та розвитку просторового притаманного лише певному регіону конгломерату продуктивних сил.

Системно-структурний підхід пов'язаний 3 необхідністю дослідження розміщення продуктивних сил на всіх територіальних рівнях, аналізу відносин і різноманітних зв'язків, які інтегрують окремі компоненти продуктивних сил в єдине ціле, а також поєднують їх з іншими територіальними системами вищого або нижчого рівня.

Історичний підхід дає можливість відстежувати розгортання процесу розміщення продуктивних сил у часі, виявляти закономірності та принципи цього процесу з точки зору певних історичних умов, певної епохи.

Комплексний підхід орієнтує дослідника на всебічний аналіз розміщення продуктивних сил у взаємозв'язку з внутрішніми і зовнішніми чинниками та процесами, передбачає визначення збалансованості та пропорційності розвитку і розміщення продуктивних сил, виявлення взаємозв'язків і взаємозалежностей між усіма їхніми компонентами.

Екологічний підхід полягає в пошуку динамічної рівноваги процесів суспільного споживання і відновлення природних ресурсів. При цьому слід враховувати деякі екологічні обмеження діяльності територіальних соціальноекономічних систем.

Проблемний підхід зосереджує свою увагу на суперечностях в суспільному розвитку.
Своєрідне удосконалення проблемного підходу дало змогу сорормувати програмно-цільовий підхід, основною і необхідною умовою якого $€$ скінченність проблеми. Забезпечити виконання цієї умови можна шляхом розроблення програми вирішення проблеми в часі.

Відтворювальний підхід передбачає використання в органічній єдності всіх фраз відтворювального циклу, тобто виробництва, розподілу, обміну і споживання матеріальних благ у часі та просторі.

Висновки. Територіально-галузевий аспект оцінки господарської діяльності дає змогу оптимізувати розміщення галузей національної економіки, яка базується на аналізі потреб країни загалом й окремих регіонів у певних видах продукції, наявності виробничих можливостей, трудових, енергетичних, паливних, сировинних ресурсів. Рівень забезпеченості територій (районів) наймасовішою продукцією промисловості чи сільського господарства визначається на основі територіальних балансів виробництва й розподілу продукції. Спеціалізація регіону й обмін продуктами підвищують ефективність виробництва загалом й прискорюють темпи його розвитку.

Галузевий підхід розроблений досить ґрунтовно і має значний вплив на прийняття рішень. До галузевого підходу існував підхід, що за критерієм мінімізації витрат моделював розташування певного підприємства в певному місці дислокації ресурсів (паливо, сировина, напівфрабрикат, працівники) та споживачів готової продукції.

\section{СПИСОК ВИКОРИСТАНИХ ДЖЕРЕЛ:}

1. Горкин А.П., Гохман В.М. Факторы размещения производства в региональных исследованиях за рубежом. Региональные исследования за рубежом. Москва : Наука, 1973. С. 86-108.

2. Державна служба статистики України. URL: http://www.ukrstat.gov.ua/

3. Колосовский Н.Н. Теория экономического районирования. Москва : Мысль, 1969. 335 с.

4. Регионы Украины: Поиск стратегии оптимального развития / Под ред. А.П. Голикова. Харьков : Харьковский ун-т, 1994. 304 с.

5. Ющенко І.О. Нормативно-правове забезпечення екологічної безпеки транскордонних територій України і напрями його удосконалення. Економіка природокористування і охорони довкілля : щорічник наук. праць. 2006. № 1. C. $70-77$.

6. Burgess, J.W. (1886) The American commonwealth: Changes in its relation to the nation. Political Science Quarterly. V. 1. P. 9-35.

7. Burton R.P. (1970) The metropolitan state. Washington, DC : The Urban Institute, $234 \mathrm{p.}$

8. Canty D. (1972) Metropolity. City. P. 39-40.

9. Garreau J. (1981) Nine nations of North America. Boston : Houghton Mifflin, 90 p.

10. Hansen N. (1988) Economic development and regional heterogeneity: a reconsideration of regional policy for the United States. Economic Development Quarterly. V. 2(2). P. 112-118.

11. Harris J. R. (1984) Economics: Invisible, productive, and problem cities. Cities of the mind: Images and themes of the city in the social sciences; in L. Rodwin \& R. M. Hollister (Eds.). New York : Plenum. P. 32-39.

12. Hoselitz B. (1953) The role of cities in the economic growth of underdeveloped countries. Journal of Political Economy. P. 56-67. 
13. Jacobs J. (1984) Cities and the wealth of nations: Principles of economic life. New York: Random House, $217 \mathrm{p}$. 14. Lampard E.E. (1955) The history of cities in the economically advanced areas. Economic Development and Cultural Change. P. 45-56.

15. Patton S.N. (1988) The decay of state and local governments. Annals of the American Academy of Political Science. V. 1(1). P. $26-42$.

16. Savitch H.V., Collins D., Sanders D. (1993) Ties that bind: Central cities, suburbs and the new metropolitan region. Economic Development Quarterly. V. 7(4). P. 341-357.

17. Tugwell R.G. (1972) Reforming the Constitution: An imperative for modern America. Oxford : Clio Press, $325 \mathrm{p}$.

18. Voith R. (1992) City and suburban growth: Substitutes or complements? Business review. Philadelphia: Federal Reserve Bank of Philadelphia. P. 21-33.

19. Zelinsky W. (1980) North America's vernacular regions. Annals of the Association of American Geographers. V. $70(1)$. P. $124-133$.

\section{REFERENCES:}

1. Gorkin A.P., Gokhman V.M. (1973) Faktory razmeshcheniya proizvodstva v regional'nykh issledovaniyakh za rubezhom [Factors of production location in regional studies abroad]. Regional'nyye issledovaniya za rubezhom. Moskva: Nauka, pp. 86-108. (in Russian)

2. Derzhavna sluzhba statistiki Ukraîhi [State Statistics Service of Ukraine]. URL: http://www.ukrstat.gov.ua/

3. Kolosovskiy N.N. (1969) Teoriya ekonomicheskogo rayonirovaniya [The theory of economic regionalization]. Moskva: Mysl', 335 p. (in Russian)

4. Regiony Ukrainy: Poisk strategii optimal'nogo razvitiya (1994) [Regions of Ukraine: Search for an optimal development strategy] / Pod red. A.P. Golikova. Khar'kov: Khar'kovskiy un-t, 304 p. (in Russian)

5. Yushchenko I.O. (2006) Normativno-pravove zabezpechennya yekologichnoi bezpeki transkordonnikh teritoriy Ukraini í napryami yogo udoskonalennya [Regulatory legal protection of the ecological safety of the transcordon territories of Ukraine and directly from the point of view]. Yekonomika prirodokoristuvannya i okhoroni dovkillya: shchoríchnik nauk. prats', no. 1, pp. 70-77. (in Ukrainian)

6. Burgess, J.W. (1886) The American commonwealth: Changes in its relation to the nation. Political Science Quarterly, v. 1, pp. 9-35.

7. Burton R.R. (1970) The metropolitan state. Washington, DC: The Urban Institute, $234 \mathrm{p.}$

8. Canty D. (1972) Metropolity. City, pp. 39-40.

9. Garreau J. (1981) Nine nations of North America. Boston: Houghton Mifflin, $90 \mathrm{p}$.

10. Hansen N. (1988) Economic development and regional heterogeneity: a reconsideration of regional policy for the United States. Economic Development Quarterly, v. 2(2), pp. 112-118.

11. Harris J.R. (1984) Economics: Invisible, productive, and problem cities. Cities of the mind: Images and themes of the city in the social sciences; in L. Rodwin \& R. M. Hollister (Eds.). New York: Plenum, pp. 32-39.

12. Hoselitz B. (1953) The role of cities in the economic growth of underdeveloped countries. Journal of Political Economy, pp. 56-67.

13. Jacobs J. (1984) Cities and the wealth of nations: Principles of economic life. New York: Random House, $217 \mathrm{p}$.

14. Lampard E.E. (1955) The history of cities in the economically advanced areas. Economic Development and Cultural Change, pp. 45-56.

15. Patton S.N. (1988) The decay of state and local governments. Annals of the American Academy of Political Science, v. 1(1), pp. 26-42.

16. Savitch H.V., Collins D., Sanders D. (1993) Ties that bind: Central cities, suburbs and the new metropolitan region. Economic Development Quarterly, v. 7(4), pp. 341-357.

17. Tugwell R.G. (1972) Reforming the Constitution: An imperative for modern America. Oxford: Clio Press, $325 \mathrm{p}$.

18. Voith R. (1992) City and suburban growth: Substitutes or complements? Business review. Philadelphia: Federal Reserve Bank of Philadelphia, pp. 21-33.

19. Zelinsky W. (1980). North America's vernacular regions. Annals of the Association of American Geographers, v. 70(1), pp. 124-133. 